\title{
KONTRIBUSI SIKAP DISIPLIN DAN MOTIF BERKOMPETISI TERHADAP KOMPETENSI PENGETAHUAN IPS SISWA KELAS IV
}

\author{
Putu Adelia Tamayanti1 ${ }^{1}$ I Wayan Sujana², I Wayan Wiarta ${ }^{3}$ \\ 1 Jurusan Pendidikan Dasar, Universitas Pendidikan Ganesha, Singaraja, Indonesia \\ ${ }_{2}^{2} J u r u s a n$ Pendidikan Dasar, Universitas Pendidikan Ganesha, Singaraja, Indonesia \\ 3Jurusan Pendidikan Dasar, Universitas Pendidikan Ganesha, Singaraja, Indonesia \\ e-mail: \{adeliatamayanti27@gmail.com ${ }^{1}$,sujanawyn59@gmail.com²,wayan.wiarta@yahoo.com³
}

\begin{abstract}
Abstrak
Penelitian ini bertujuan untuk mengetahui pengaruh yang signifikan sikap disiplin dan motif berkompetisi terhadap kompetensi pengetahuan IPS siswa kelas IV SDN Gugus Mohhamad Hatta Kecamatan Denpasar Selatan Tahun Ajaran 2018/2019. Penelitian ini merupakan penelitian ex post facto. Populasi penelitian ini seluruh siswa kelas IV SDN Gugus Mohhamad Hatta Kecamatan Denpasar Selatan Tahun Ajaran 2018/2019 berjumlah 243 siswa. Sampel ditentukan dari populasi menggunakan teknik proportional random sampling. Jumlah sampel dari populasi adalah 142 siswa. Metode teknik pengumpulan data menggunakan metode non tes berupa pencatatan dokumen dan angket. Data sikap disiplin dan motif berkompetisi diperoleh melalui angket, data kompetensi pengetahuan IPS melalui pencatatan dokumen. Setelah data diperoleh, dilakukan uji prasyarat analisis dengan uji normalitas Kolmogorov-Smirnov, uji linearitas, uji multikolinearitas dan uji heteroskedastisitas. Data penelitian yang telah memenuhi uji prasyarat analisis diuji menggunakan analisis statistik inferensial dengan teknik analisis regresi ganda. Hasil penelitian menunjukkan pengaruh yang signifikan antara sikap disiplin dan motif berkompetisi terhadap kompetensi pengetahuan IPS berdasarkan nilai $\mathrm{F}_{\text {hitung }}=3,13>\mathrm{F}_{\text {tabel }}=3,07$ dengan kontribusi sebesar 4,3\%. Sikap disiplin dan motif berkompetisi memberikan kontribusi sebesar 4,3\% terhadap kompetensi IPS pada siswa kelas IV SDN Gugus Mohhamad Hatta Kecamatan Denpasar Selatan. Sehingga 95,7\% lainnya dipengaruhi oleh faktor belajar lain baik faktor dari dalam maupun faktor dari luar diri siswa. Adapun saran ditujukan kepada guru untuk lebih mengoptimalkan sikap disiplin dan motif berkompetisi dalam pembelajaran guna dapat mencapai kompetensi pengetahuan IPS.
\end{abstract}

\begin{tabular}{l} 
Keywords: \\
\hline Disiplin, \\
berkompetisi, \\
kompetensi \\
pengetahuan IPS
\end{tabular}

\section{Pendahuluan}

Pendidikan merupakan kebutuhan yang sangat penting yang berfungsi untuk meningkatkanmutu kehidupan manusia. Pendidikan juga berperan penting dalam 
mempersiapkan dan mengembangkan sumber daya manusia yang handal dan mampu bersaing secara sehat sebagaimana tujuan pendidikan itu sendiri. Oleh karena itu, setiap orang hendaknya mendapatkan pendidikan yang layak.

Pendidikan sangat membantu peserta didik dalam usaha mengembangkan dan menitik beratkan pada pengembangan pengetahuan, kecakapan, dan nilai sikap serta pola tingkah laku yang berguna bagi hidupnya. Pendidikan berbasis karakter kini mulai dilirik oleh banyak pihak, karena memiliki potensi besar untuk diimplementasikan di dalam proses pembelajaran. Pendidkan karakter yang merupakan pendidikan yang sangat menekankan pada aspek nilai yang diharapkan akan lahir manusia yang memiliki sensitivitas tinggi terhadap penegakan nilainilai kebenaran, keadilan, kemanusiaan, dan kemajuan yang merupakan nafas (ruh) dalam kehidupan manusia di bumi ini

Pada saat ini pendidikan mengalami perubahan yakni perubahan kurikulum pembelajaran dari KTSP menjadi Kurikulum 2013. Pendidikan karakter dalam kurikulum 2013 hadir dengan tujuan untuk meningkatkan mutu proses dan hasil pendidikan, yang mengarah pada pembentukan budi pekerti dan akhlak mulia peserta didik secara utuh, terpadu dan seimbang sesusi dengan Standar Kompetensi Lulusan (SKL) pada setiap satuan pendidikan. Implementasi kurikulum 2013 yang berbasis kompetensi sekaligus karakter, dengan pendekatan tematik dan kontekstual peserta didik mampu secara mandiri meningkatkan dan menggunakan pengetahuannya, mengkaji dan menginternalisasi serta mempersonalisasi nilai-nalai karakter dan akhlak mulia sehingga terwujud dalam perilaku sehari-hari.

Penilaian pencapaian kompetensi pengetahuan merupakan bagian dari penilaian pendidikan. Proses penilaian terhadap kompetensi dapat memberikan informasi tentang kemajuan peserta didik dalam upaya mencapai tujuan-tujuan belajarnya melalui kegiatan belajar atau pembelajaran terutama dalam mata pelajaran IPS. Selain untuk memberikan penilaian evaluasi juga sebagai alat memotivasi belajar siswa. Kompetensi pengetahuan IPS adalah perubahan perilaku siswa yang mencerminkan kemampuan siswa terhadap penguasaan pembelajaran IPS dari segi pengetahuan setelah mengalami proses belajar.

Hakikat pembelajaran IPS di SD memberikan pengetahuan dasar dan keterampilan sebagai media pelatihan bagi siswa sebagai warga negara sedini mungkin. Susanto (2013:137) "IPS adalah ilmu yang pengetahuan yang mengkaji berbagai disiplin ilmu sosial dan humaniora serta kegiatan dasar manusia yang dikemas secara ilmiah dalam rangka memberi wawasan dan pemahaman yang mendalam kepada peserta didik khususnya di tingat dasar dan menengah". Dapat dirangkum dari beberapa difinisi tersebut bahwa pendidikan IPS di SD adalah harapan untuk membina siswa yang berhubungan erat dengan pengetahuan, keterampilan, sikap dan nilai-nilai untuk mencapai sebuah kesuksesan dalam belajar.

Dalam mencapai sebuah kesuksesan dalam belajar tentu perlu adanya pembentukan karakter. Pembentukan karakter sangat berguna bagi peserta didik dalam proses pembentukan kepribadian mereka sebagai generasi penerus bangsa. Salah satu karakter yang dapat dikembangkan berupa karakter sikap disiplin. Menurut Tulus (2008:33), disiplin berarti mengikuti dan menaati peraturan, nilai, dan hukum yang berlaku. Pengikutan dan ketaatan tersebut terutama muncul karena adanya kesadaran diri bahwa hal itu berguna bagi kebaikan dan keberhasilan dirinya. Dapat juga muncul karena rasa takut, tekanan, paksaan dan dorongan dari luar dirinya..

Berdasarkan pendapat itu, sikap disiplin merupakan salah satu bagian terpenting dalam pembentukan karakter bangsa khususnya bagi siswa sekolah dasar. Dimana jika seorang peserta didik sudah mampu memahami apa yang diinginkan dan apa yang harus dilakukan untuk hidup terasa lebih nyaman, menyenangkan, sehat, dan sukses. Judul Selain sikap disiplin, faktor lain yang mempengaruhi proses belajar adalah motif berkompetisi. adanya kompetisi sebagai suatu kebutuhan bagi individu maka dibutuhkan motif untuk menggerakkan individu bertingkah laku yang mempunyai tujuan tertentu, yaitu tujuan untuk memenangkan 
persaingan demi peningkatan prestasi”. Motif berkompetisi yang dimiliki siswa adalah sebagai kebutuhan dalam meraih suatu prestasi, maka siswa mampu mengontrol belajarnya dan mampu menyesuaikan diri untuk tetap bersikap disiplin dalam menyusun tugas-tugas dan tujuan yang ingin dicapai dalam suatu kompetisi guna mencapai suatu peningkatan dalam suatu belajarnya. Dengan demikian, yang dapat menunjang kompetensi pengetahuan IPS adalah sikap disiplin yang akan mengkondisikan dirinya bertingkah laku sesuai aturan dalam menempuh kegiatan pembelajaran, sehingga dapat menumbuhkan motif berkompetisi dan dapat mencapai tujuan pembelajaran secara optimal.

Motif berkompetisi juga menjadi salah satu faktor yang dapat menunjang kompetensi pengetahuan IPS. Motif berkompetisi yang dimiliki siswa akan menumbuhkan sikap yang positif dan optimis dalam dirinya serta dapat meningkatkan prestasi disekolahnya dengan memandang kompetisi sebagai motivator bagi dirinya.

Berdasakan pentingnya sikap disiplin dan motif berkompetisi siswa dalam meningkatkan kompetensi pengetahuan IPS, maka penelitian ini dilakukan untuk mengetahui kontribusi antara sikap disiplin dan motif berkompetisi terhadap komptensi pengetahuan IPS. Penelitian ini akan dilakukan dengan judul "Kontribusi Sikap Disiplin Dan Motif Berkompetisi Terhadap Kompetensi Pengetahuan IPS Siswa Kelas IV SDN Gugus Mohhamad Hatta Tahun Ajaran $2018 / 2019$

\section{Metode}

Penelitian ini dilaksanakan pada kelas IV SDN Gugus Mohhamad Hatta Kecamatan Denpasar Selatan. Pemilihan SDN Gugus Mohhamad Hatta Kecamatan Denpasar Selatan sebagai tempat penelitian karena keterjangkaua dan kelayakan. Keterjangkauan dalam arti tempat penelitian mudah dijangkau oleh peneliti, serta kelayakan dalam arti di SDN Gugus Mohhamad Hatta Kecamatan Denpasar Selatan belum pernah dilakukan penelitian yang sama dengan penelitian ini. Penelitian ini merupakan penelitian Ex Post Facto Korelasional, penelitian yang dilakukan untuk meneliti suatu peristiwa yang telah terjadi dan kemudian merunut ke belakang tentang faktor-faktor yang dapat menyebabkan timbulnya kejadian tersebut. Sehingga penelitian ini tidak memberikan perlakuan khusus terhadap variabel penelitian, melainkan hanya mengungkap fakta-fakta yang ada berdasarkan pengukuran gejala yang telah terjadi pada responden sebelum penelitian ini dilakukan. Metode penelitian menunjuk pada perlakuan atau manipulasi variabel bebas $\mathrm{X}$ telah terjadi sehingga penelitian tidak perlu memberikan perlakuan lagi, tinggal melihat efeknya pada variabel terikat. Dalam penelitian ini menggunakan 2 variabel bebas (X1 dan X2 ) dan 1 variabel terikat (Y). Adapun variabel tersebut adalah Sikap Disiplin sebagai X1, Motif Berkompetisi sebagai X2, dan Kompetensi Pengetahuan IPS sebagai Y.

Penelitan ini bertujuan untuk mengetahui pengaruh yang signifikan sikap disiplin dan motif berkompetisi terhadap kompetensi IPS, dengan tidak memanipulasi variabel bebas atau menggali fakta yang sudah terjadi sebelumnya. Setiap penelitian didasarkan adanya masalah dan objek yang diteliti. Antara satu penelitian dengan penelitian lainnya memiliki subjek yang yang berbeda-beda bergantung pada konteks penelitian. Populasi memegang peranan penting dalam sebuah penelitian. Populasi tidak hanya orang tetapi juga objek dan benda-benda alam yang lainnya. Menurut Agung (2012:47) "Populasi adalah keseluruhan objek dalam suatu penelitian". "Populasi adalah wilayah generalisasi yang terdiri atas obyek/subyek yang mempunyai kualitas dan karakteristik tertentu yang ditetapkan oleh peneliti untuk dipelajari dan kemudian ditarik kesimpulannya" (Sugiyono, 2015:117).

Jadi berdasarkan kutipan diatas populasi bukan hanya orang, tetapi juga objek dan bendabenda alam yang lain. Populasi juga bukan sekedar jumlah yang ada pada objek/subjek yang dipelajari, tetapi meliputi seluruh karakteristik/sifat yang dimiliki oleh subjek atau objek itu. Populasi dalam penelitian ini adalah semua kelas IV SDN Gugus Mohhamad Hatta yang terdiri 
dari 5 sekolah negeri. Adapun sekolah tersebut yaitu SD Negeri 1 Panjer, SD Negeri 2 Panjer, SD Negeri 3 Panjer, SD Negeri 4 Panjer, SD Negeri 6 Panjer. Populasi dalam penelitian ini adalah siswa kelas IV SDN Gugus Mohhamad Hatta Kecamatan Denpasar Selatan Tahun Ajaran 2018/2019 yang berjumlah 243 siswa. Berdasarkan tabel Issac and Michael, jumlah populasi yang terdapat di SDN Gugus Mohhamad Hatta Kecamatan Denpasar Selatan adalah 243 orang siswa dan jumlah sampel yang diambil berdasarkan tingkat kesalahan 5\% berjumlah 142 siswa. Bila populasi besar, penelitian yang dilakukan akan sulit mempelajari semua yang ada pada populasi, misalnya karena keterbatasan tenaga dan waktu, maka dapat digunakanlah sampel yang diambil dari populasi itu. Sutrisno (dalam Narbuko dan Achmadi, 2013:107) "Sampel adalah sebagian individu yang diselidiki dari keseluruhan individu penelitian". Sedangkan menurut Sugiyono (2015:118) mengemukakan bahwa "sampel adalah bagian dari jumlah dan karakteristik yang dimiliki oleh populasi tersebut".

Jadi dapat disimpulkan sampel adalah sebagian atau wakil dari jumlah dan karakteristik populasi yang diteliti. Dalam melakukan penelitian banyak sekali teknik sampel yang ada, namun untuk penelitian ini, teknik yang digunakan dalam mengambil sampel adalah teknik sampling proporsional random sampling. Menurut Sugiyono (2015:120) "teknik proporsional sampel digunakan bila populasi memiliki anggota atau unsur yang tidak homogen dan berstrata secara porporsional". Proporsional sampel merupakan jumlah sampel yang diambil dari strata yang sebanding, sesuai dengan proporsional ukurannya. Random sampling adalah pengambilan sampel secara acak yaitu pengambilan sampel yang tanpa pilih-pilih (Narbuku dan Achmadi,2013). Jadi teknik proporsional random sampling adalah teknik pengambilan sampel secara acak dengan memperhatikan jumlah siswa dari masing-masing kelas. Dalam penentuan sampel dapat dilihat pada tabel Isaac and Michael. Dalam tabel tersebut dijelaskan tentang besarnya sampel yang diambil dari populasi dengan tingkat kesalahan 5\%. Sesuai dengan tabel Isaac dan Michael, jumlah populasi di gugus Mohhamad Hatta sebanyak 243 orang, jadi jumlah sampel yang diambil dengan tingkat kesalahan 5\% adalah 142 orang. "Penentuan ukuran sampel dapat ditulis dengan pendekatan rumus dari Isaac dan Michael" (Sugiyono 2015:128) dan dari pendekatan rumus tersebut didapatlah jumlah sampel dari populasi, yang kemudian dicari tiap-tiap sampel dari sebaran populasi yang ada di kelas IV SDN gugus Mohhamad Hatta Kecamatan Denpasar Selatan

Untuk memperoleh data atau informasi dalam penelitian perlu dilakukan kegiatan pengumpulan data. Data yang dikumpulkan dalam penelitian ini adalah data sikap disiplin dan data motif berkompetisi siswa kelas IV SDN Gugus Mohhamad Hatta Kecamatan Denpasar Selatan Tahun ajaran 2018/2019. Dalam proses pengumpulan data tertentu diperlukan sebuah alat atau instrument pengumpulan data. Dalam penelitian ini metode pengumpulan data yang digunakan yaitu nontes. Dalam penelitian ini menggunakan teknik nontes yang digunakan untuk mendapatkan data dari variabel yaitu kuesioner atau angket. Untuk memperolah data atau informasi dalam penelitian perlu dilakukan kegiatan pengumpulan data. Dalam proses pengumpulan data tertentu diperlukan sebuah alat atau instrumen pengumpulan data. Dalam penelitian ini teknik pengumpulan data dapat dilakukan dengan kuisioner (angket). "Kuesioner atau angket merupakan teknik pengumpulan data yang dilakukan dengan cara memberi seperangkat pertanyaan atau pernyataan tertulis kepada responden untuk dijawabnya" (Sugiyono, 2015:199). "Metode kuesioner atau angket merupakan cara memperoleh atau mengumpulkan data dengan mengirimkan surat daftar pertanyaan/ pertanyaan - pertanyaan kepada responden/ subjek penelitian" (Agung, 2014:99). Jadi dapat dirangkum angket yaitu teknik pengumpulan data dengan cara memberikan daftar pernyataan secara tertulis kepada subjek peneliti. Sugiyono (2015:199) menyatakan "angket digunakan apabila responden jumlahnya besar dan dapat membaca dengan baik, angket juga digunakan untuk dapat mengungkapkan hal-hal yang sifatnya rahasia". Dalam penelitian ini menggunakan dua angket untuk memperoleh data yaitu angket sikap disiplin dan angket motif berkompetisi. 
Kuesioner penelitian ini menggunakan skala Likert sebagai skala pengukuran sikap disiplin dan motif berkompetisi. Skala Likert digunakan untuk mengukur sikap, pendapat, dan persepsi seseorang atau sekelompok orang tentang fenomena sosial. "Dengan skala Likert maka variabel yang akan diukur menjadi indikator variabel. Kemudian indikator tersebut dijadikan sebagai titik tolak untuk menyusun item-item instrumen yang berupa pernyataan atau pertanyaan" (Sugiyono, 2015:134).

Bentuk kuesioner yang digunakan adalah kuesioner berstuktur dengan bentuk jawaban tertutup dimana jawabannya telah tersedia dan responden menjawab setiap pertanyaan dengan cara memilih alternatif jawaban yang telah disediakan. Kuesioner dengan model skala Likert ini akan memudahkan responden dalam menjawab pertanyaan atau pernyataan yang telah disediakan dalam kueisioner tersebut. Cara pemberian skor untuk statemen yang positif pilihan sangat setuju skornya 4, setuju skornya 3, tidak setuju skornya 2, dan sangat tidak setuju skornya 1. Sedangkan, untuk statemen yang negatif pilihan sangat setuju skornya 1, setuju skornya 2, tidak setuju skornya 3, dan sangat tidak setuju skornya 4. (Sugiyono, 2015:135).

Kuesionner sikap disiplin dan motif berkompetisi sebagai alat ukur untuk mengetaui sejauh mana sikap disiplin dan motif berkompetisi yang dimiliki siswa kelas IV SDN Gugus Mohhamad Hatta Kecamatan Denpasar Selatan Tahun Ajaran 2018/2019. Jumlah item kuesioner yaitu 30 butir pernyataan. Pengujian instrumen dalam penelitian ini menggunakan validitas butir instrumen dan validitas konstruk. Jika seorang peneliti atau seorang guru mengetahui bahwa validitas instrumen misalnya terlalu rendah atau rendah saja, maka selanjutnya ingin mengetahui butir-butir instrumen manakah yang menyebabkan soal secara keseluruhan tersebut jelek karena memiliki validitas rendah. Untuk keperluan inilah dicari validitas butir soal. Arikunto (2012:90) menjelaskan bahwa "validitas instrumen adalah demikian sebuah item dikatakan valid apabila mempunyai dukungan yang besar terhadap skor total". Skor pada item menyebabkan skor total menjadi tinggi rendah. Dengan kata lain dapat dikemukakan di sini bahwa sebuah item memiliki validitas yang tinggi jika skor pada item mempunyai kesejajaran dengan skor total. Sedangkan Untuk menguji validitas konstruk, dapat digunakan pendapat para ahli (judgement expert). Dalam hal ini setelah instrumen dikontruksi tentang aspek-aspek yang akan diukur dengan berlandaskan teori tertentu, maka selanjutnya dikonsultasikan dengan ahli. Sugiyono (2015:177) menyatakan, validitas konstruk yaitu, sebuah instrumen menunjuk suatu kondisi sebuah instrumen yang disusun berdasarkan konstruk yang akan diukur berlandasan teori tertentu selanjutnya dikonsultasikan kepada ahli materi (judgement expert).

Jadi berdasarkan pemaparan diatas dapat dirangkum dalam melakukan pengujian instrumen untuk menguji kevalidan butir kuesioner menggunaan validitas logis yang meliputi validitas isi dan validitas konstruk. Validitas isi digunakan untuk menguji isi dari kuesioner dari segi indikator dan dibuatkan dalam bentuk kisi-kisi sedangkan validitas konstrak untuk mengukur teori yang akan dikonsultasikan kepada ahli materi.

Pencatatan dokumen merupakan cara untuk memperoleh data yang dilakukan dengan mengumpulkan segala jenis dokumentasi seperti tulisan, gambar, karya-karya manual ataupun yang sejenisnya untuk kemudian di catat secara sistematis. "Dokumen bisa berbentuk tulisan, gambar, atau karya-karya monumental dari seseorang" (Sugiyono, 2015:329). Sedangkan Agung (2012:65) menyatakan bahwa "Dokumen merupakan cara memperoleh data dengan jalan mengumpulkan segala macam dokumen dan melakukan pencatatan secara sistematis". Sebagaian besar data yang tersedia yaitu berbentuk surat, catatan harian, laporan. Berdasarkan pemaparan diatas maka yang dimaksud dengan dokumen adalah cara memperoleh data dengan jalan mengumpulkan segala macam dokumen seperti tulisan, gambar, karya-karya manual ataupun yang sejenisnya untuk kemudian di catat secara sistematis.

Penggunaan dokumen dalam penelitian yang dilakukan ini adalah salah satu penunjang dalam teknik pengumpulan data dengan mengumpulkan dokumen-dokumen yang dapat 
mendukung serta melengkapi data dari penelitian yang dilakukan. Adapun data yang dikumpulkan melalui pencatatan dokumen ini adalah nilai UAS semester 1 pada muatan pembelajaran IPS siswa kelas IV SDN Gugus Mohhamad HattaKecamatan Denpasar Selatan Tahun Ajaran 2018/2019.

Metode analisis data merupakan hal terpenting dalam sebuah penelitian. Analisis data adalah salah satu proses penelitian yang dilakukan setelah data terkumpul yang diperlukan untuk memecahkan masalah yang diteliti. Tujuan analisis data adalah untuk mengadakan generalisasi terhadap sifat-sifat, kondisi-kondisi, atau hubungan-hubungan yang bersifat khusus sehingga diperoleh, kondisi-kondisi, sifat-sifat atau hubungan-hubungan yang bersifat umum (Agung, 2014: 109).

Setelah data dikumpulkan data tersebut dilakukan analisis. Analisis dalam penelitian ini menggunakan analisis statistik inferensial. Statistik inferensial ini digunakan untuk menarik simpulan mengenai keseluruhan data dari populasi. "Statistik inferensial merupakan bidang ilmu statistika yang mempelajari tentang tata cara penarikan kesimpulan - kesimpulan mengenai keadaan populasi, berdasarkan hasil analisis data terhadap bagian dari populasi yang disebut sampel" (Sugiyono, 2015:208). Dalam penelitian ini teknik analisis yang digunakan adalah uji regresi linear berganda. Teknik analisis data yang digunakan teknik analisis regresi sederhana dan analisis regresi ganda. Untuk memenuhi persyaratan uji hipotesis maka diperlukan uji persyaratan analisis yaitu uji normalitas, uji linearitas, uji multikolenearitas, uji heteroskedastisida dan uji hipotesis statistik.

Uji normalitas digunakan untuk menguji apakah data variabel bebas dan variabel terikat berdistribusi normal atau tidak, dengan cara menggunakan rumus kolmogorov-smirnov dengan Kriteria pengujian adalah apabila nilai maksimum $\left|\mathrm{F}_{\mathrm{T}}-\mathrm{F}_{\mathrm{S}}\right| \leq$ nilai tabel Kolmogorov-Smirnov, maka data berdistribusi normal.

Uji linearitas digunakan untuk mengetahui linieritas data, yaitu apakah dua variabel mempunyai hubungan yang linear atau tidak atau tidak secara signifikan (Purnomo,2016:94). Uji linearitas menggunakan tabel ANAVA atau analysis of varians dengan kriteria f hitung kurang dari $f$ tabel maka dinyatakan linear. Uji linearitas dengan tabel ANAVA juga menunjukan nilai signifikan dengan kriteria $\mathrm{F}$ hitung regresi lebih dari $\mathrm{f}$ tabel pada taraf signifikansi $5 \%$ maka $\mathrm{F}$ regresi tersebut signifikan.

Uji multikolinearitas dimaksudkan untuk mengetahui ada tidaknya hubungan (korelasi) yang cukup tinggi antara semua variabel bebas yaitu sikap disiplin dan motif berkompetisi. Model regresi yang baik seharusnya tidak terjadi multikolinearitas (Purnomo,2016:94). Teknik yang digunakan untuk mencari multikolinearitas adalah menggunakan modul Regression Linear dari program SPSS 25.0 for Windows dengan kriteria nilai VIF kurang dari 10,0 dan nilai tolerance lebih dari 0,10 maka dapat dinyatakan tidak terjadi multikolinearitas.

Uji Heteroskedastisitas merupakan varians variabel dalam model tidak sama. Regresi yang baik seharusnya tidak terjadi heteroskedastisitas. Uji Heteroskedastisitas yang digunakan adalah Uji Glejser. Uji Glejser dilakukan dengan cara meregresikan antara variabel independen dengan nilai absolut residualnya. Teknik yang digunakan adalah modul Regression Linear dari program SPSS 25.0 for Windows dengan kriteria nilai signifikansi variabel lebih dari nilai signifikansi 0,05 maka dapat dinyatakan tidak terjadi masalah heteroskedastisitas.

Metode analisis data merupakan hal terpenting dalam sebuah penelitian. Analisis data adalah salah satu proses penelitian yang dilakukan setelah data terkumpul yang diperlukan untuk memecahkan masalah yang diteliti. Tujuan analisis data adalah untuk mengadakan generalisasi terhadap sifat-sifat, kondisi-kondisi, atau hubungan-hubungan yang bersifat khusus sehingga diperoleh, kondisi-kondisi, sifat-sifat atau hubungan-hubungan yang bersifat umum. Uji hipotesis yang dilakukan adalah uji hipotesis dengan menggunakan teknik analisis regresi 
sederhana dan teknik analisis regresi ganda. Menurut Siregar (2017:220), "kegunaan regresi adalah untuk meramalkan atau memprediksi variabel terikat (Y) apabila variabel bebas (X) diketahui "kegunaan regresi adalah untuk meramalkan atau memprediksi variabel terikat (Y) apabila variabel bebas (X) diketahui". Untuk uji hipotesis akan digunakan teknik analisis regresi sederhana untuk menguji koefisien kontribusi antar variabel bebas (sikap disiplin dan motif berkompetisi) terhadap variabel terikat (kompetensi pengetahuan IPS) adapun hipotesis I dan II yang diuji adalah hipotesis nol (Ho) yang menyatakan (1) yang berbunyi tidak terdapat pengaruh yang signifikan sikap disiplin terhadap kompetensi pengetahuan IPS pada siswa kelas IV SDN Gugus Mohamad Hatta Kecamatan Denpasar Selatan Tahun Ajaran 2018/2019. Ho (2) yang berbunyi yang berbunyi tidak terdapat pengaruh yang signifikan motif berkompetisi terhadap kompetensi pengetahuan IPS pada siswa kelas IV SDN Gugus Mohhamad Hatta Kecamatan Denpasar Selatan Tahun Ajaran 2018/2019, Ho (3) yang berbunyi tidak terdapat pengaruh yang signifikan sikap disiplin dan motif berkompetisi terhadap kompetensi pengetahuan IPS pada siswa kelas IV SDN Gugus Mohhamad Hatta Kecamatan Denpasar Selatan Tahun Ajaran 2018/2019.

\section{Hasil dan Pembahasan}

Data mengenai kompetensi pengetahuan IPS siswa kelas IV SDN Gugus Mohhamad Hatta Kecamatan Denpasar Selatan Tahun Ajaran 2018/2019. diperoleh melalui pencatatan dokumen, dokumen tersebut adalah daftar nilai ulangan akhir semester I, dengan meminta ijin kepada guru wali kelas masing-masing. Pencatatan dokumen sesuai dengan jumlah responden yaitu 142 responden.

Data tentang sikap disiplin siswa kelas IV SDN Gugus Mohhamad Hatta Kecamatan Denpasar Selatan Tahun Ajaran 2018/2019 diperoleh melalui penyebaran angket sikap disiplin. Sampel yang dibagikan angket sikap disiplin sebanyak 142 responden dan diberikan dengan 30 pernyataan. Deskripsi data ini disajikan dengan Microsoft Excel 2013 serta disajikan juga dengan cara manual yang dimasukkan ke dalam tabel.

Data tentang motif berkompetisi siswa kelas IV SDN Gugus Mohhamad Hatta Kecamatan Denpasar Selatan Tahun Ajaran 2018/2019 diperoleh melalui penyebaran angket motif berkompetisi. Sampel yang dibagikan angket motif berkompetisi sebanyak 142 responden dan diberikan dengan 30 pernyataan.

Deskripsi data ini disajikan dengan Microsoft Excel 2013 serta disajikan juga dengan cara manual yang dimasukkan ke dalam tabel.

Uji normalitas dilakukan guna mengetahui residual data berdistribusi normal atau tidak. Kriteria nilai maksimum $\left|\mathrm{F}_{\mathrm{T}}-\mathrm{F}_{\mathrm{S}}\right|>\mathrm{KS}_{\text {tabel }}$ dengan taraf signifikansi $5 \%$ maka data tidak berdistribusi normal. Sikap disiplin terhadap kompetensi pengetahuan IPS mendapatkan nilai maksimum $\left|F_{T}-F_{S}\right|=0,041$ kurang dari KS tabel= 0,114 dan nilai Asymp Sig (2 tailed)=0,200 lebih dari signifikansi 0,05, maka dapat disimpulkan data berdistribusi normal. Motif berkompetisi terhadap kompetensi pengetahuan IPS mendapatkan nilai maksimum 0,041 kurang dari KS tabel=0,114 dan nilai Asymp Sig (2 tailed)=0,971 lebih dari signifikansi 0,05, maka dapat disimpulkan data berdistribusi normal. Sikap disiplin dan motif berkompetisi terhadap kompetensi pengetahuan IPS mendapatkan nilai maksimum $\left|F_{T}-F_{S}\right|=0,036$ kurang dari KS tabel= 0,114 dan nilai Asymp Sig (2 tailed)=0,933 lebih dari signifikansi 0,05, maka dapat disimpulkan data berdistribusi normal.

Uji prasyarat yang kedua adalah uji linearitas menggunakan tabel analysis of varians (ANAVA), dengan tabel ANAVA dapat diketahui secara bersamaan $F_{\text {signifikan }}$ dan $F_{\text {linear. }}$ (1) Dari hasil uji linearitas sikap disiplin dengan kompetensi pengetahuan IPS didapat bahwa hasil menunjukkan $\mathrm{F}_{\text {hitung }}=0,646<\mathrm{F}_{\text {tabel }}=3,91$ pada taraf signifikansi $5 \%$ maka regresi $\mathrm{Y}$ dan $\mathrm{X}$ dinyatakan linear. Uji linearitas dengan tabel ANAVA juga menunjukan nilai signifikan yaitu 
$\mathrm{F}_{\text {hitung }}=4,558>\mathrm{F}_{\text {tabel }}=3,91$ pada taraf signifikansi 5\% maka $\mathrm{F}$ regresi tersebut signifikan, (2) dari hasil uji linearitas motif berkompetisi dengan kompetensi pengetahuan IPS didapat bahwa hasil menunjukkan $F_{\text {hitung }}=0,855<\mathrm{F}_{\text {tabel }}=3,91$ pada taraf signifikansi $5 \%$ maka regresi $\mathrm{Y}$ dan $\mathrm{X}$ dinyatakan linear. Uji linearitas dengan tabel ANAVA juga menunjukan nilai signifikan yaitu $\mathrm{F}_{\text {hitung }}=6,046>\mathrm{F}_{\text {tabel }}=3,91$ pada taraf signifikansi 5\% maka $\mathrm{F}$ regresi tersebut signifikan. Begitu pula berdasarkan hasil perhitungan SPSS menggunakan Test for Linearity mendapatkan hasil signifikan (linearity) kurang dari 0,05, maka data sikap disiplin dengan kompetensi pengetahuan IPS dan data motif berkompetisi dengan kompetensi pengetahuan IPS dinyatakan linear.

Selanjutnya uji prasyarat yang ketiga adalah uji multikolinearitas dapat diketahui hasil nilai VIF Sikap disiplin 2,166 < 10,0 begitu pula dengan nilai VIF motif berkompetisi 2,166 < 10,0 maka nilai VIF kurang dari 10,0 untuk semua variabel bebas, demikian pula nilai tolerance sikap disiplin 0,426 > 0,10 dan nilai tolerance sikap rasa ingin tahu 0,466 >0,10 maka nilai tolerance lebih dari 0,10 untuk semua variabel bebas. Dengan demikian, maka tidak terjadi multikolinearitas antar variabel bebas.

Untuk uji prasyarat yang terakhir adalah dengan melakukan uji heteroskedistisitas dari hasil yang didapat diketahui bahwa nilai signifikansi sikap disiplin yaitu 0,896 $>0,05$ dan nilai signifikansi motif berkompetisi yaitu 0,805 >0,05. Kedua variabel independen lebih dari 0,05 dengan demikian dapat disimpulkan bahwa tidak terjadi masalah heteroskedastisitas pada model regresi pada data penelitian ini.

Berdasarkan hasil analisis uji prasyarat analisis (uji normalitas data, uji linearitas, uji multikolinearitas dan uji heteroskedastisida) tersebut, dapat disimpulkan bahwa uji prsayarat dalam melakukan uji hipotesis telah terpenuhi. Dengan demikian, pengujian hipotesis dengan menggunakan teknik analisis regresi sederhana dan regresi ganda dapat dilanjutkan. Pengujian hipotesis pertama menggunakan analisis uji regresi linier sederhana dengan persamaan garis regresi $\widehat{Y}=60,459+0,161 X$ Hubungan sikap disiplin $\left(\mathrm{X}_{1}\right)$ dengan kompetensi pengetahuan IPS (Y) ditunjukkan oleh koefisien korelasi $\mathrm{r}_{\mathrm{xy}}=0,178$ Berdasarkan uji koefisien korelasi pada taraf signifikan 5\% dengan $\mathrm{dk}=142$ diperoleh $\mathrm{r}_{\text {tabel }}=0,159$ maka dengan demikian $\mathrm{r}_{\text {hitung }}=0,178>$ $r_{\text {tabel }}=0,159$ ini berarti korelasi sikap disiplin dengan kompetensi pengetahuan IPS memiliki hubungan positif. Koefisien determinasi adalah $\mathrm{R}^{2}=0,032$ atau sebesar 3,2\%, variasi kompetensi pengetahuan IPS ditentukan oleh sikap disiplin.

Hal ini menandakan bahwa $\mathrm{H}_{0}$ yang menyatakan tidak terdapat pengaruh yang signifikan sikap disiplin terhadap kompetensi pengetahuan IPS pada siswa kelas IV SDN Gugus Mohhamad Hatta Kecamatan Denpasar Selatan Tahun Ajaran 2018/2019 ditolak dan $\mathrm{H}_{\mathrm{a}}$ terdapat pengaruh yang signifikan sikap disiplin terhadap kompetensi pengetahuan IPS pada siswa kelas IV SDN Gugus Mohhamad Hatta Kecamatan Denpasar Selatan Tahun Ajaran 2018/2019. Pengujian hipotesis kedua menggunakan analisis uji regresi linier sederhana dengan persamaan garis

regresi $\widehat{\mathrm{Y}}=58,319+0,181 \mathrm{X}$. Hubungan motif berkompetisi $\left(\mathrm{X}_{2}\right)$ dengan kompetensi pengetahuan IPS (Y) ditunjukkan oleh koefisien korelasi $r_{\mathrm{xy}}=0,203$ Berdasarkan uji koefisien korelasi pada taraf signifikan $5 \%$ dengan $\mathrm{dk}=142$ diperoleh $r_{\text {tabel }}=0,159$ maka dengan demikian $r_{\text {hitung }}=0,203>r_{\text {tabel }}=0,159$ ini berarti korelasi motif berkompetisi dengan kompetensi pengetahuan IPS memiliki hubungan positif. Koefisien determinasi adalah $\mathrm{R}^{2}=$ 0,041 atau sebesar $4,1 \%$, variasi kompetensi pengetahuan IPS ditentukan oleh motif berkompetisi $\mathrm{Hal}$ ini menandakan bahwa $\mathrm{H}_{0}$ yang menyatakan tidak terdapat pengaruh yang signifikan motif berkompetisi terhadap kompetensi pengetahuan IPS pada siswa kelas IV SDN Gugus Mohhamad Hatta Kecamatan Denpasar Selatan Tahun Ajaran 2018/2019 ditolak dan $\mathrm{H}_{\mathrm{a}}$ terdapat pengaruh yang signifikan sikap motif berkompetisi terhadap kompetensi pengetahuan IPS pada siswa kelas IV SDN Gugus Mohhamad Hatta Kecamatan Denpasar Selatan Tahun Ajaran 2018/2019 diterima. 
Pengujian hipotesis ketiga menggunakan analisis uji regresi linier ganda dengan persamaan garis regresi $\widehat{Y}=56,794+0,055 X_{1}+0,141 X_{2}$. Hubungan sikap disiplin $\left(\mathrm{X}_{1}\right)$ dan motif berkompetisi $\left(\mathrm{X}_{2}\right)$ dengan kompetensi pengetahuan IPS $(\mathrm{Y})$ ditunjukkan oleh koefisien korelasi $\mathrm{r}_{\mathrm{xy}}=0,208$ Berdasarkan uji koefisien korelasi pada taraf signifikan $5 \%$ dengan $\mathrm{dk}=142$ diperoleh $r_{\text {tabel }}=0,159$ maka dengan demikian $r_{\text {hitung }}=0,208>r_{\text {tabel }}=0,159$ ini berarti korelasi sikap disiplin dan motif berkompetisi secara bersama-sama dengan kompetensi pengetahuan IPS memiliki hubungan positif. Koefisien determinasi adalah $\mathrm{R}^{2}=4,313$ atau sebesar 4,3\%, variasi kompetensi pengetahuan IPS ditentukan oleh sikap disiplin dan motif berkompetisi.

Hal ini menandakan bahwa $\mathrm{H}_{0}$ yang menyatakan tidak terdapat pengaruh yang signifikan sikap disiplin dan motif berkompetisi terhadap kompetensi pengetahuan IPS pada siswa kelas IV SDN Gugus Mohhamad Hatta Kecamatan Denpasar Selatan Tahun Ajaran 2018/2019 ditolak dan $\mathrm{H}_{\mathrm{a}}$ terdapat pengaruh yang signifikan sikap disiplin dan motif berkompetisi terhadap kompetensi pengetahuan IPS pada siswa kelas kelas IV SDN Gugus Mohhamad Hatta Kecamatan Denpasar Selatan Tahun Ajaran 2018/2019 diterima.

Kontribusi sikap disiplin dan motif berkompetisi secara bersama-sama tehadap kompetensi pengetahuan IPS adalah sebesar 4,3\%. dapat dikatakan bahwa masih terdapat $95,7 \%$ faktor lain yang mempengaruhi variabel kompetensi pengetahuan IPS yaitu faktor internal dan faktor eksternal. Faktor internal merupakan faktor yang bersumber dari dalam diri siswa yaitu kecerdasan, minat, bakat, motivasi, kebiasaan belajar, kesiapan atau kematangan. Sedangkan faktor eksternal merupakan faktor yang bersumber dari luar diri siswa yaitu berupa status ekonomi keluarga, pola asuh orang tua, kualitas pengajaran di sekolah, metode belajar di sekolah, fasilitas belajar, dan lingkungan belajar. kompetensi guru.

Hasil penelitian menujukkan bahwa pencapaian kompetensi pengetahuan IPS siswa adalah adanya sikap disiplin dan motif berkompetisi. Disiplin merupakan salah satu bagian terpenting dalam pembentukan karakter bangsa, khususnya bagi siswa sekolah dasar dalam menerapkan disiplin pada siswa sekolah dasar tidak dapat dipisahkan dari masalah tata tertib. Disiplin sangatlah penting untuk seorang siswa agar dapat berhasil dalam mencapai tujuan belajar. Dengan disiplin siswa dapat lebih terarah dalam melaksanakan kegiatan belajar, jadi disiplin merupakan cerminan langsung dari kepatuhan seorang siswa dalam melaksanakan tata tertib sekolah. Proses disiplin tercipta melalui pembiasan-pembiasan yang dilakukan secara sadar atau tidak sadar, secara sukarela atau terpaksa, serta secara konsisten terus dilakukan. Proses tersebut kemudian membentuk sebuah perilaku yang disiplin. Perilaku disiplin yang berkelanjutan akan memudahkan siswa dalam melaksanakan kegiatan belajar, membantu pertumbuhan mental, kepribadian, serta akan sangat berdampak dengan prestasi belajar. Hal ini sejalan dengan penelitian yang dilakukan oleh Diatmika (2017) mengungkapkan bahwa sikap disiplin memiliki hubungan dengan kompetensi pengetahuan IPS, dengan hasil dengan hasil analisis data diperoleh $\mathrm{t}_{\text {hitung }}=2,803$, sedangkan pada taraf signifikansi $5 \%$ dan dk 98 diperoleh nilai $t_{\text {tabel }} 1,980$ sehingga $t_{\text {hitung }}=2,803>t_{\text {tabel }}=1,980$.

Pada hasil penelitian ini juga menunjukkan bahwa pencapaian kompetensi pengetahuan IPS tidak terlepas dari adanya sikap disiplin yang dimiliki siswa, tetapi juga adanya suatu motif berkompetisi. Motif Berkompetisi diartikan sebagai dorongan individu melakukan suatu usaha untuk mencapai tujuan dengan cara bersaing untuk memperoleh hasil yang lebih baik dari orang lain. Motif berkompetisi yang dimiliki oleh siswa adalah sebagai kebutuhan dalam meraih suatu prestasi, maka siswa mampu mengontrol belajarnya dan mampu menyesuaikan diri dalam menyusun tugas-tugas dan tujuan yang ingin dicapai dalam suatu kompetisi guna mencapai suatu peningkatan dalam prestasi belajarnya. Motif berkompetisi yang dimiliki siswa akan menumbuhkan sikap yang positif dan optimis dalam dirinya serta dapat meningkatkan prestasi di sekolahnya dengan memandang kompetisi sebagai motivator bagi dirinya. Hal ini sejalan dengan penelitian yang dilakukan oleh Muna (2010) mengungkapkan bahwa adanya hubungan kemandirian dengan motif berkompetisi dengan hasil analisis data koefisien korelasi sebesar 
0,431 dengan nilai $p=0,000(p<0,05)$ menunjukkan bahwa terdapat hubungan yang signifikan antara variabel kemandirian dengan motif berkompetisi pada siswa.

Dari hasil pembahasan tersebut, maka dapat disimpulkan yaitu terdapat pengaruh sikap disiplin terhadap kompetensi pengetahuan IPS siswa kelas IV SDN Gugus Mohhamad Hatta Kecamatan Denpasar Selatan Tahun Ajaran 2018/2019, terdapat pengaruh motif berkompetisi terhadap kompetensi pengetahuan IPS siswa kelas IV SDN Gugus Mohhamad Hatta Kecamatan Denpasar Selatan Tahun Ajaran 2018/2019 dan terdapat pengaruh yang signifikan sikap disiplin dan motif berkompetisi terhadap kompetensi pengetahuan IPS siswa kelas IV SDN Gugus Mohhamad Hatta Kecamatan Denpasar Selatan Tahun Ajaran 2018/2019.

\section{Simpulan}

Berdasarkan analisis data yang telah dilaksanakan maka dapat diketahui bahwa, terdapat pengaruh yang signifikan sikap disiplin terhadap kompetensi pengetahuan IPS siswa kelas IV SDN Gugus Mohhamad Hatta Kecamatan Denpasar Selatan Tahun Ajaran 2018/2019 nilai $r_{\text {hitung }}$ $=0,178>r_{\text {tabel }}=0,159(\mathrm{dk}=124)$ pada taraf signifikansi $5 \%$ dengan persamaan regresi $\widehat{\mathrm{Y}}=$ $60,459+0,161 \mathrm{X}$ dan koefisien determinasi $\mathrm{R}^{2}=0,032$ maka diperoleh kontribusi sebesar 3,2\% sikap disiplin terhadap kompetensi pengetahuan IPS.

Terdapat pengaruh yang signifikan Motif berkompetisi terhadap kompetensi pengetahuan IPS siswa kelas IV SDN Gugus Mohhamad Hatta Kecamatan Denpasar Selatan Tahun Ajaran $2018 / 2019$ dengan nilai $r_{\text {hitung }}=0,203>r_{\text {tabel }}=0,159(\mathrm{dk}=142)$ pada taraf signifikansi $5 \%$

dengan persamaan regresi $\widehat{\mathrm{Y}}=58,319+0,181 \mathrm{X}$ dan koefisien determinasi $\mathrm{R}^{2}=0,041$ maka diperoleh kontribusi sebesar 4,1\% motif berkompetisi terhadap kompetensi pengetahuan IPS.

Terdapat pengaruh yang signifikan sikap disiplin dan motif berkompetisi terhadap kompetensi pengetahuan IPS siswa kelas IV SDN Gugus Mohhamad Hatta Kecamatan Denpasar Selatan Tahun Ajaran 2018/2019 dengan nilai $r_{\text {hitung }}=0,208>r_{\text {tabel }}=0,159$ (dk=142). Begitu pula dilihat pada uji $\mathrm{F}$ pada taraf signifikansi menunjukan bahwa $\mathrm{F}_{\text {hitung }}=3,13$ dan $\mathrm{F}_{\text {tabel }}=3,06$

$(\mathrm{dk}=142)$ pada taraf signifikansi $5 \%$ dengan persamaan regresi $\widehat{Y}=56,794+0,055 X_{1}+0,141 X_{2}$ dan koefisien determinasi $\mathrm{R}^{2}=0,043$ maka diperoleh kontribusi sebesar 4,3\% sikap disiplin dan motif berkompetis terhadap kompetensi pengetahuan IPS.

Dengan hasil data tersebut dapat dikatakan bahwa masih terdapat 95,7\% faktor lain yang mempengaruhi variabel kompetensi pengetahuan IPS yaitu faktor internal dan faktor eksternal. Faktor internal merupakan faktor yang bersumber dari dalam diri siswa yaitu kecerdasan, minat, bakat, motivasi, kebiasaan belajar, kesiapan atau kematangan. Sedangkan faktor eksternal merupakan faktor yang bersumber dari luar diri siswa yaitu status ekonomi keluarga, pola asuh orang tua, kualitas pengajaran di sekolah, metode belajar di sekolah, fasilitas belajar, dan lingkungan belajar.

Dengan demikian dapat disimpulkan bahwa sikap disiplin mempengaruhi kompetensi pengetahuan IPS siswa kelas IV SDN Gugus Mohhamad Hatta Kecamatan Denpasar selatan Tahun Ajaran 2018/2019, motif berkompetisi mempengaruhi kompetensi pengetahuan IPS siswa kelas IV SDN Gugus Mohhamad Hatta Kecamatan Denpasar selatan Tahun Ajaran 2018/2019 serta sikap disiplin dan motif berkompetisi secara bersama-sama mempengaruhi kompetensi pengetahuan IPS siswa kelas IV SDN Gugus Mohhamad Hatta Kecamatan Denpasar selatan Tahun Ajaran 2018/2019.

Sebagai tindak lanjut dari hasil penelitian, maka penelitian ini disarankan kepada: (1) berdasarkan temuan penelitian, kepada siswa disarankan untuk meningkatkan sikap disiplin dan motif berkompetisi agar dapat mengikuti pembelajaran dengan baik sehingga tercapainya kompetensi pengetahuan IPS yang optimal. (2) kepada guru, hasil penelitian ini dapat menjadi masukan yang positif dan berharga sebagai dasar meningkatkan kemampuan membentuk 
Sikap disiplin dan motif berkompetisi siswa, (3) Kepala Sekolah, hasil penelitian ini dapat menjadi masukan berharga bagi Kepala Sekolah selaku pengambil kebijakan yang nantinya kebijakan tersebut dapat memperlancar kegiatan pembelajaran, (4) kepada Peneliti Lain, hasil penelitian ini dapat dijadikan sebagai salah satu referensi bagi para peneliti bidang pendidikan sebagai bahan untuk mendalami objek penelitian yang sejenis.

\section{Daftar Pustaka}

Agung, Gede. 2011. Metodelogi Penelitian Pendidikan. Malang: Aditya Media Publising Agung, Gede. 2012. Metodelogi Penelitian Pendidikan. Malang: Aditya Media Publising. Agung, Gede. 2014. Metodelogi Penelitian Pendidikan. Malang: Aditya Media Publising. Arikunto, Suharsimi. 2012. Dasar-dasar Evaluasi Pendidikan. Jakarta: Bumi Aksara.

B.Uno, Hamza. 2017. Teori Motivasi dan Pengukuranya. Jakarta: Bumi Akasara.

Daryanto dan Suryati Darmiatum. 2013. Implementasi Pendidikan Karakter di Sekolah Dasar. Jakarta: Prenadamedia Group.

Diatmika. 2017. Korelasi Antara Sikap Disiplin Dalam Belajar Dengan Kompetensi Pengetahuan IPS Siswa Kekas VI SD Gugus 1 Kecamatan Mengwi Tahun Pelajaran 2016/2017. Universitas Pendidikan Ganesha. Volume 1, Nomor 3. (Diakses pada tanggan 16 November 2018)

Kurniasih, Sani. 2017. Pendidikan Karakter. Jakarta: Kata Pena.

Kosasih. 2014. Strategi Belajar dan Pembelajaran. Bandung: YramaWidya

Muna, Hartati, Setyawan. Hubungan Antara Kemandirian Dengan Motif Berkompetisi Pada Siswa Kelas VII Rintisan Sekolah Bertaraf Internasional: Fakultas Psikologi Universitas Diponogoro. (Diakses pada tanggal 16 November 2018)

Narbuko dan Achmadi. 2013. Metodelogi Penelitian. Jakarta: Bumi Aksara

Santosa, Slamet. 2006. Dinamika Kelompok. Jakarta: Bumi Aksara.

Sayomukti, Nurani. 2016. Pengantar Sosiologi. Jogjakarta: Ar-Ruzz Media.

Siregar, Syofian. 2017. Statistik Terapan untuk Perguruan Tinggi. Jakarta:Kencana

Slameto. 2013. Belajar dan Faktor-Faktor yang Mempengaruhi. Jakarta: Rineka Cipta.

Soekanto, Soerjono. 2009. Sosiologi Suatu Pengantar. Jakarta: Rajawali Pers.

Sudijono, Anas. 2015. Pengantar Evaluasi Pendidikan. Jakarta: Prenanmedia Grop

Sugiyono. 2015. Metodelogi Penelitian Pendidikan. Bandung: Alfabeta.

Sugiyono. 2017. Metodelogi Penelitian Pendidikan. Bandung: Alfabeta.

Susanto, Ahmad. 2013. Teori Belajar \& Pembelajaran di Sekolah Dasar. Jakarta: Pranadamedia Grup.

Susanto, Ahmad. 2018. Bimbingan dan Konseling di Sekolah Dasar. Jakarta: Pranadamedia Grup.

Tu'u, Tulus. 2008. Peran Disiplin Pada Perilaku dan Prestasi Siswa. Jakarta: PT Grasindo.

Peraturan Pemerintah Republik Indonesia nomor 21 Tentang Standar Isi Pendidikan Dasar Dan Menengah, 2016. Jakarta: Kemendikbud

Peraturan Mentri Dan Kebudayaan Republik Indonesia Nomor 24 Tahun 2016. Tentang Kompetensi Inti dan Kompetensi Dasar. Jakarta: Kemendikbud

Peraturan Menteri Pendidikan dan Kebudayaan Republik Indonesia Nomor 57 Tentang Kurikulum 2013 Sekolah Dasar/Madrasah Ibtidaiyah, 2014. Jakarta: Kemendikbud.

Purnomo, Aldi Rochmat. 2016. Analisis Statistik Ekonomi dan Bisnis dengan SPSS. Ponorogo: CV Wage Grup 